Syntax Literate: Jurnal Ilmiah Indonesia p-ISSN: 2541-0849 e-ISSN: 2548-1398

Vol. 6, Special Issue No. 2, Desember 2021

\title{
MENINGKATKAN PENGETAHUAN TEORI PERSAMAAN DIFERENSIAL DAN TRANSFORMASI LAPLACE MELALUI PEMBELAJARAN KOOPERATIF MODEL STAD
}

\section{Mudjiono}

Politeknik Negeri Malang (Polinema), Indonesia

Email: mudjiono@polinema.ac.id

\begin{abstract}
Abstrak
Setidaknya ada tiga komponen yang berhubungan dengan pembaharuan pendidikan, yaitu pembaharuan kurikulum, peningkatan kualitas pembelajaran, dan efektifitas metode pembelajaran. Kondisi lapangan yang menunjukkan bahwa mahasiswa hanya bisa menghafal fakta-fakta dan rumus tetapi tidak bisa menerapkannya pada masalah-masalah diluar matematika mendorong peneliti melakukan penelitian ini. Untuk itu metode pembelajaran sebagai salah satu komponen tersebut perlu ditingkatkan terus. Penelitian ini bertujuan untuk mencari sebuah solusi yang "mungkin" bisa menjawab kondisi tersebut serta lebih sesuai dengan ciri dan tujuan pendidikan di Politeknik, khususnya Politeknik Negeri Malang. Melalui metode ini diharapkan siswa bisa lebih proaktif dalam membangun pengetahuannya sendiri sehingga siswa mampu mengkaitkan konsepkonsep matematika menjadi satu kesatuan yang utuh., dan setelah keluar dari Politeknik siswa mampu mengaktualisasikan konsep-konsep tersebut dalam berbagai persoalan yang ada, khususnya persoalan yang berkaitan dengan masalah kelistrikan.

Penelitian ini lebih dominan pada aspek kualitatif namun untuk membahasnya perlu data kuantitatif sebagai pendukung, sehingga metode yang digunakan dalam penelitian ini meliputi metode kualitatif dan kuantitatif.

Berdasarkan hasil penelitian ini setelah melalui tiga kali tindakan kelas, target yang diinginkan sudah bisa dicapai, yaitu tercapainya proses belajar mengajar yang melampaui skor minimal $80 \%$ dan nilai rata-rata kelas di atas skor minimal 65. Akhirnya peneliti berkesimpulan bahwa metode pembelajaran kooperatif model STAD ini bisa diterapkan di Politeknik, khususnya Politeknik Negeri Malang terkhusus lagi di program studi Teknik Listrik.
\end{abstract}

Kata kunci: metode STAD; skor peningkatan individu; Robert Slavin; pembelajaran kooperatif, pembelajaran tradisional.

\section{Abstract}

There are at least three components related to educational reform, namely curriculum renewal, improving the quality of learning, and the effectiveness of learning methods. Field conditions which show that students can only memorize facts and formulas but cannot apply them to problems outside of mathematics encourage researchers to conduct this research. For this reason, the learning method as one of these components needs to be improved continuously. This study

\begin{tabular}{ll} 
How to cite: & Mudjiono (2021) Meningkatkan Pengetahuan Teori Persamaan Diferensial dan Transformasi Laplace \\
& Melalui Pembelajaran Kooperatif Model STAD, Syntax Literate: Jurnal Ilmiah Indonesia 6(22), \\
& http://dx.doi.org/10.36418/syntax-literate.v6i6 \\
E-ISSN: & $2548-1398$ \\
Published by: & Ridwan Institute \\
\hline
\end{tabular}


aims to find a solution that "may" be able to answer these conditions and is more in line with the characteristics and objectives of education at the Polytechnic, especially the State Polytechnic of Malang. Through this method, it is hoped that students can be more proactive in building their own knowledge so that students are able to link mathematical concepts into a unified whole, and after leaving the Polytechnic students are able to actualize these concepts in various existing problems, especially problems related to electrical problem.

This research is more dominant in the qualitative aspect but to discuss it, quantitative data is needed as a support, so the methods used in this research include qualitative and quantitative methods.

Based on the results of this study after going through three class actions, the desired target has been achieved, namely the achievement of the teaching and learning process that exceeds a minimum score of $80 \%$ and the class average score is above a minimum score of 65. Finally the researcher concluded that the STAD model learning method can be applied in Polytechnics, especially the State Polytechnic of Malang, especially in the Electrical Engineering study program.

Keywords: STAD method; individual improvement scores; Robert Slavin; cooperative learning; traditional learning.

\section{Pendahuluan}

Pendidikan adalah sebagai usaha sadar dan terencana untuk mewujudkan suasana belajar dan proses pembelajaran untuk peserta didik secara aktif mengembangkan potensi dirinya untuk memiliki kekuatan spiritual keagamaan, pengendalian diri, kepribadian, kecerdasan, akhlak mulia, serta keterampilan yang diperlukan dirinya dan masyarakat (MUIS, 2020). Selama ini pembelajaran Matematika Terapan di Politeknik Negeri Malang, khususnya di jurusan Teknik Listrik lebih banyak menggunakan pendekatan tradisional (konvensional), yaitu salah satu paham pembelajaran behavioristik yang lebih banyak menempatkan mahasiswanya sebagai objek pembelajaran. Pada metode ini mahasiswa lebih banyak menjadi objek pembelajaran dari pada pelaku pembelajaran, karena pengetahuan lebih banyak ditransfer oleh dosen kepada mahasiswa. Dengan demikian peran mahasiswa dalam membangun pengetahuannya sendiri dianggap kurang. Akibatnya mahasiswa hanya mampu menghapal fakta-fakta dan rumus tetapi kurang terampil dalam menerapkan dan mengitegrasikannya dengan disiplin ilmu lainnya, khususnya ilmu kelistrikan. Selain itu pembelajaran tradisional tersebut cenderung membentuk pribadi yang individualis karena sarana untuk berinteraksi secara social kurang.

Vygotsky (Hudojo, 2005) menyatakan bahwa potensi siswa (X) dapat berkembang efektif menuju potensi $(\mathrm{X}+1)$ jika dalam pembelajaran yang terjadi melibatkan faktorfaktor dari luar terutama guru/dosen dan teman siswa. (gambar 1). Agar interaksi antara siswa-dosen lebih efektif, maka peran dosen menurut Vygotsky mengacu pada ZPD, intersubjektivitas dan Scaffolding. 


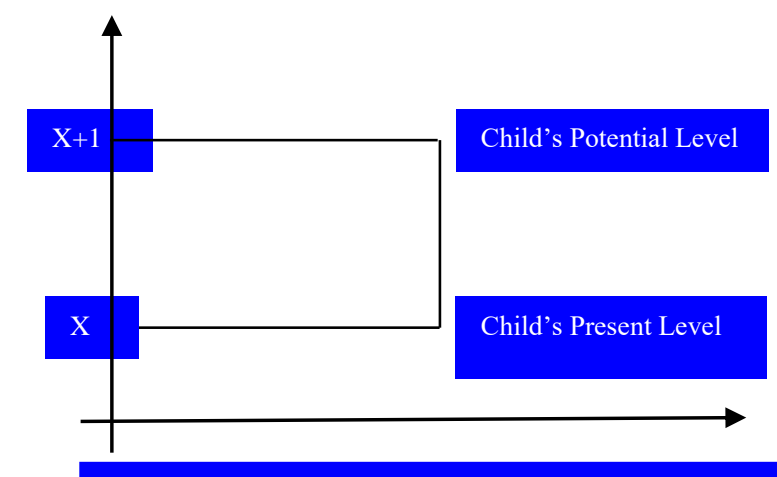

Gambar 1 Zona Proximal Development (ZPD)

\section{Gambar 1 \\ Zona Proximal Development (ZPD)}

Selain itu agar nantinya mahasiswa tidak canggung terjun di dunia kerja dan masyarakat, mahasiswa perlu dibekali dengan ketrampilan social secukupnya. Untuk itu pembelajaran kooperatif bisa diujicobakan dalam pembelajaran ini, karena dalam pembelajaran kooperatif diajarkan ketrampilan social. Abdurrahman dan Bintoro dalam (Nurhadi \& Senduk, 2004) menyatakan bahwa pembelajaran kooperatif adalah suatu sistem pembelajaran yang di dalamnya memuat berbagai elemen yang saling berkaitan, antara lain (1) saling ketergantungan secara positif, (2) interaksi tatap muka, (3) akuntabilitas individual, dan (4) ketrampilan untuk menjalin hubungan antara pribadi atau ketrampilan sosial.

Penjabaran masing-masing elemen tersebut adalah sebagai berikut (Nurhadi \& Senduk, 2004)

(1) Saling ketergantungan secara positif,

Dalam pembelajaran kooperatif, dosen perlu menciptakan suasana yang bisa mendorong mahasiswa untuk saling membutuhkan. Hubungan yang saling membutuhkan itulah yang disebut sebagai saling ketergantungan positif. Saling ketergantungan positif ini menuntut adanya interaksi yang memungkinkan mahasiswa merasa saling memberi motivasi sehingga bisa meraih hasil belajar yang lebih baik.

(2) Interaksi Tatap Muka

Interaksi tatap muka menuntut para mahasiswa dalam kelompok untuk bisa saling bertatap muka sehingga mereka dapat melakukan dialog, tidak hanya dengan dosen tetapi dengan sesama anggota kelompok. Melalui interaksi semacam ini memungkinkan seorang mahasiswa menjadi sumber pembelajaran bagi mahasiswa lain dalam kelompoknya, sehingga dosen atau bahan bacaan tidak menjadi satu-satunya sumber pembelajaran.

(3) Akuntabilitas Individual

Pembelajaran kooperatif terimplementasikan melalui belajar kelompok. Sekalipun demikian penilaian ditujukan untuk mengetahui kemampuan mahasiswa secara individual terhadap bahan ajar yang dipelajari. Hasil belajar secara invidual tersebut selanjutnya diberitahukan kepada kelompok agar setiap anggota kelompok mengetahui 
siapa yang perlu dibantu dan siapa yang perlu membantu. Nilai kelompok didasarkan pada rata-rata hasil belajar semua anggota kelompok, sehingga setiap anggota kelompok harus mempunyai andil dalam kelompoknya. Penilaian kelompok yang didasarkan dari rata-rata semua anggota kelompok inilah yang disebut sebagai akuntabilitas inividual

(4) Ketrampilan untuk menjalin hubungan antara pribadi pribadi sengaja diajarkan.

Dalam pembelajaran kooperatif ketrampilan sosial seperti tenggang rasa, santun terhadap teman, mengkritik dan menerima ide peserta lain, berani mempertahankan argumen yang logis, tidak mendominasi pembicaraan, dan berbagai aspek lain yang bermanfaat dalam menjalin hubungan antara sesama anggota sengaja diajarkan.

Salah satu bentuk pembelajaran kooperatif yang paling sederhana adalah pembelajaran kooperatif metode STAD. Pembelajaran kooperatif metode STAD ini dikembangkan oleh Robert Slavin dan kawan-kawannya di Universitas Hopkins. Dalam pelaksanaannya para siswa dibagi dalam kelompok-kelompok kecil yang terdiri dari 4 sampai 5 orang. Setiap kelompok terdiri dari anggota-anggota yang heterogen.

Menurut (Slavin, 2008), metode STAD mempunyai 5 komponen utama dimana salah satu komponen merupakan tahapan dari komponen lainnya, yaitu: (a) penyajian kelas, (b) belajar dalam kelompok, (c) tes/kuis individu, (d) skor peningkatan individu, dan (e) penghargaan kelompok.

Penjabaran kelima komponen tersebut adalah sebagai berikut.

a. Penyajian kelas

Penyajian materi dalam metode STAD ini tidak berbeda jauh dengan penyajian materi secara tradisional, hanya saja penyajian lebih difokuskan kepada materi yang akan diajarkan.

b. Belajar dalam kelompok.

Para mahasiswa dibagi dalam kelompok-kelompok kecil yang terdiri dari 4 sampai 5 orang. Anggota - anggota kelompok disusun secara beragam, artinya secara proporsional setiap kelompok memuat berbagai kriteria yang ada, antara lain kemampuan akademik, etnis, agama, asal sekolah, dan jenis kelamin.

c. Tes/Kuis Individu

Setelah dosen menyajikan materi antara 1 sampai dengan 2 minggu, dan mahasiswa belajar secara kooperatif dalam bentuk kelompok-kelompok, dosen memberikan tes secara perorangan. Disamping untuk melihat tingkat pemahaman mahasiswa terhadap materi yang baru dipelajari, tes ini bermanfaat untuk memacu mahasiswa belajar lebih serius.

d. Skor Peningkatan Individu.

Esensi diadakannya skor peningkatan individu adalah untuk memberikan peluang kepada siswa untuk mencapai nilai terbaiknya jika siswa yang bersangkutan dengan bantuan teman kelompoknya telah berusaha maksimal. Skor peningkatan individu siswa ditentukan berdasarkan selisih skor kuis saat ini dengan skor kuis terdahulu. Bagi siswa yang tidak bisa memperoleh skor yang lebih baik tetap diberi nilai agar siswa 
termotivasi terus belajarnya. Menurut (Slavin, 2008) kriteria skor peningkatan individu tersebut dirumuskan pada tabel 1 berikut ini.

Tabel 1

Kriteria Skor Peningkatan Individu. (Slavin, 2008)

\begin{tabular}{lc}
\hline Skor tes mahasiswa & Skor peningkatan individu \\
\hline Lebih dari 10 poin di bawah skor awal & 0 \\
\hline Antara 1 sampai 10 poin di bawah skor awal & 10 \\
\hline Antara 0 sampai 10 poin di atas skor awal & 20 \\
\hline Lebih dari 10 poin di atas skor awal & 30 \\
\hline Pekerjaan sempurna & 30 \\
\hline
\end{tabular}

e. Penghargaan kelompok

Setelah dilakukan perhitungan skor peningkatan individu, langkah selanjutnya adalah memberikan hadiah sebagai bentuk penghargaan terhadap kelompok yang mencapai kriteria tertentu. Skor kelompok dihitung dengan cara menjumlahkan skor individu dalam kelompok dibagi dengan banyaknya anggota kelompok.

Berdasarkan berbagai alasan di atas, peneliti mencoba melakukan suatu terobosan dengan melakukan penelitian, tepatnya penelitian tindakan kelas yaitu pembelajaran kooperatif metode STAD. Melalui metode ini diharapkan mahasiswa lebih proaktif dalam membangun pengetahuannya sendiri sehingga nantinya mahasiswa betul-betul memiliki kemampuan standart yang kompeten dan memiliki jiwa social lebih baik.

Adapun penelitian ini bertujuan mengetahui pengaruh pembelajaran kooperatif model STAD terhadap prestasi akademik mahasiswa dan mendiskripsikan skenario pembelajaran kooperatif model STAD,

\section{Metode Penelitian}

\section{Jenis Penelitian}

Jenis penelitian ini lebih condong sebagai penelitian kualitatif karena ingin menggali temuan-temuan yang tidak bisa digali sepenuhnya melalui alat kuantifikasi. Penelitian ini akan berusaha mendiskripsikan skenario pembelajaran kooperatif metode STAD pada materi ajar Persamaan Diferensial Tingkat I dan Transformasi Laplace. Disamping data kuantitatif sebagai pendukung, data yang akan diambil berupa data kualitatif, yaitu sebuah fakta deskriptif yang berisi tentang penjelasan-penjelasan bagaimana seorang mahasiswa membangun pengetahuannya secara kooperatif serta berbagai temuan yang didapat dari peristiwa-peristiwa di lapangan selama tindakan pembelajaran berlangsung.

\section{Tahap-tahap Penelitian}

Tahap-tahap yang dilaksanakan dalam penelitian tindakan ini mengikuti aturan Kemmis \& Taggart dan digambarkan dalam diagram alur (gambar 2). 


\section{Sumber Data dan Pengolahan Data}

Data bersumber dari (1) nilai mahasiswa, (2) skor pengamatan aktivitas dosen, dan (3) skor pengamatan aktivitas mahasiswa. Nilai mahasiswa berasal dari pekerjaan siswa dalam mengerjakan tes awal, tes akhir tindakan dan tes setelah berakhirnya seluruh tindakan, selanjutnya diolah secara kuantitatif dengan merujuk pada kriteria skor peningkatan individu yang peneliti tampilkan pada tabel 1. Pengolahan data tersebut tercermin pada tabel 2. Sedangkan skor pengamatan aktivitas dosen, dan skor pengamatan aktivitas mahasiswa peneliti tampilkan pada tabel 3 dan tabel 4 .

Tabel 2

Kriteria skor peningkatan individu

\begin{tabular}{|c|c|c|c|c|c|c|}
\hline Kelompok & Subjek & $\begin{array}{c}\text { Skor Tes } \\
1\end{array}$ & Skor Tes 2 & SPI & Rata $^{2}$ & Predikat \\
\hline \multirow[t]{5}{*}{ I } & $\mathrm{M}_{11}$ & $x_{11}$ & $y_{11}$ & $s_{11}$ & $s r_{1}$ & $\mathrm{P}_{1}$ \\
\hline & $\mathrm{M}_{12}$ & $x_{12}$ & $y_{12}$ & $s_{12}$ & & \\
\hline & $\mathrm{M}_{13}$ & $x_{13}$ & $y_{13}$ & $s_{13}$ & & \\
\hline & $\mathrm{M}_{14}$ & $x_{14}$ & $y_{14}$ & $s_{14}$ & & \\
\hline & $\mathrm{M}_{15}$ & $x_{15}$ & $y_{15}$ & $S_{15}$ & & \\
\hline \multirow[t]{5}{*}{ II } & $\mathrm{M}_{21}$ & $x_{21}$ & $y_{21}$ & $s_{21}$ & $s r_{2}$ & $\mathrm{P}_{2}$ \\
\hline & $\mathrm{M}_{22}$ & $x_{22}$ & $y_{22}$ & $s_{22}$ & & \\
\hline & $\mathrm{M}_{23}$ & $x_{23}$ & $y_{23}$ & $s_{23}$ & & \\
\hline & $\mathrm{M}_{24}$ & $x_{24}$ & $y_{24}$ & $s_{24}$ & & \\
\hline & $\mathbf{M}_{25}$ & $x_{25}$ & $y_{25}$ & $s_{25}$ & & \\
\hline \multirow[t]{5}{*}{ III } & M31 & $x 31$ & y31 & $s 31$ & $s r 3$ & P3 \\
\hline & M32 & $x 32$ & $y 32$ & $s 32$ & & \\
\hline & M33 & $x 33$ & $y 33$ & $s 33$ & & \\
\hline & M34 & $x 34$ & $y 34$ & s34 & & \\
\hline & M35 & $x 35$ & y35 & $s 35$ & & \\
\hline \multirow[t]{5}{*}{ IV } & $\mathrm{M}_{41}$ & $x_{41}$ & $y_{41}$ & $s_{41}$ & $s r_{4}$ & $\mathrm{P}_{4}$ \\
\hline & $\mathrm{M}_{42}$ & $x_{42}$ & $y_{42}$ & $S_{42}$ & & \\
\hline & $\mathrm{M}_{43}$ & $x_{43}$ & $y_{43}$ & $s_{43}$ & & \\
\hline & $\mathrm{M}_{44}$ & $x_{44}$ & $y_{44}$ & $s_{44}$ & & \\
\hline & $\mathrm{M}_{45}$ & $x_{45}$ & $y_{45}$ & $S_{45}$ & & \\
\hline
\end{tabular}

Penjelasan: Nilai $s r_{\mathrm{ij}}$ tergantung dari nilai $\left(y_{\mathrm{ij}}-x_{\mathrm{ij}}\right)$

Jika $\quad\left(y_{\mathrm{ij}}-x_{\mathrm{ij}}\right)<-10$, maka nilai $s_{\mathrm{ij}}=0$

Jika $-10 \leq\left(y_{\mathrm{ij}}-x_{\mathrm{ij}}\right) \leq-1$, maka nilai $s_{\mathrm{ij}}=10$

Jika $0 \leq\left(y_{\mathrm{ij}}-x_{\mathrm{ij}}\right) \leq 10$, maka nilai $s_{\mathrm{ij}}=20$

Jika $\quad\left(y_{\mathrm{ij}}-x_{\mathrm{ij}}\right)>10$ nilai $s_{\mathrm{ij}}=30$

Pekerjaan kedua sempurna dengan skor 100, maka nilai $s_{\mathrm{ij}}=30$

$s p_{i}=\frac{\sum_{j} s_{i j}}{5}$. misalnya $s p_{3}=\frac{\sum_{j} s_{3 j}}{5}=\frac{s_{31}+s_{32}+s_{33}+s_{34}+s_{35}}{5}$

b. Skor pengamatan aktivitas dosen. 
Tabel 3

Hasil observasi pengamat terhadap kegiatan dosen di kelas

\begin{tabular}{l}
\hline Jenis Kegiatan \\
\hline Awal \\
\hline - aktivitas sehari-hari \\
\hline - menyampaikan tujuan pembelajaran \\
\hline - membangkitkan pengetahuan awal \\
\hline - menyampaikan manfaat materi \\
\hline - menyajikan materi \\
\hline Inti \\
\hline - membagikan LKM \\
\hline - membentuk kelompok \\
\hline - membimbing kerja kelompok \\
\hline - memandu diskusi kelompok \\
\hline Akhir \\
\hline - melaksanakan tes individu \\
\hline - aktivitas sehari-hari \\
\hline Jumlah skor \\
Ketuntasan: $\frac{\text { jumlahskor }}{\text { skormaksimum }} \times 100 \%=\ldots$ \\
\hline
\end{tabular}

b. Skor pengamatan aktivitas mahasiswa.

Tabel 4

Hasil observasi pengamat terhadap kegiatan mahasiswa di kelas Jenis Kegiatan skor

Awal

- memperhatikan tujuan pembelajaran

- membangkitkan pengetahuan awal

- keterlibatan memahami manfaat materi

- keterlibatan memahami penyampaian materi

Inti

- keterlibatan mengerjakan LKM

- keterlibatan dalam kelompok

- keterlibatan menyelesaikan tugas kelompok

- aktiviatas mahasiswa berkemampuan tinggi

- aktiviatas mahasiswa berkemampuan sedang

- aktiviatas mahasiswa berkemampuan rendah

- aktivitas mahasiswa dalam diskusi

\begin{tabular}{l}
\hline Akhir \\
\hline - kejujuran mengerjakan soal tes \\
\hline Jumlah skor \\
\hline Ketuntasan: $\frac{\text { jumlahskor }}{\text { skormaksimum }} \times 100 \%=\ldots$ \\
\hline
\end{tabular}




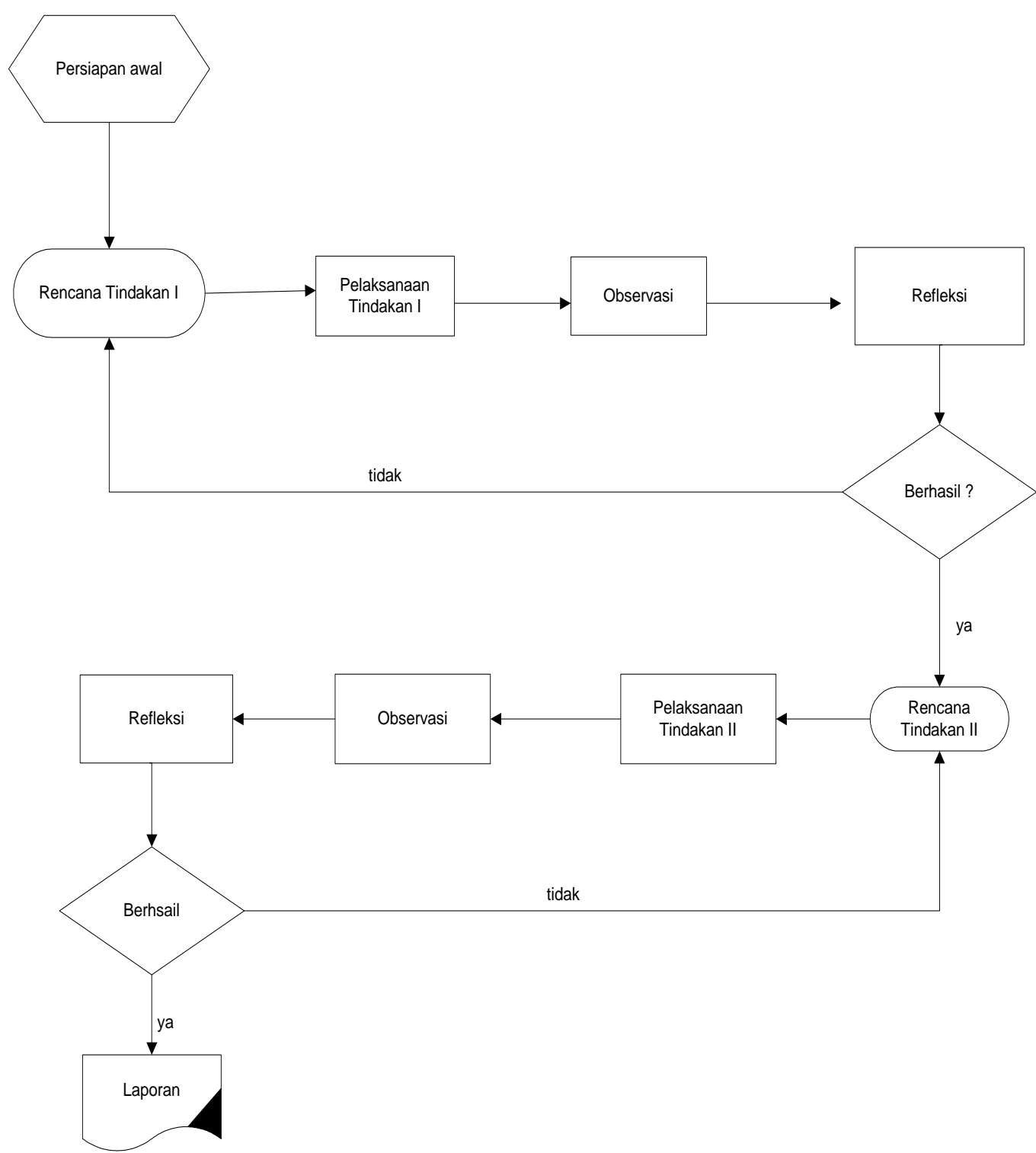

Gambar 2

Siklus penelitian tindakan yang dikembangkan oleh Kemmis dan Taggart

\section{Analisa Data}

Data pendukung yang diolah secara kuantitatif dianalisis dengan menggunakan analisis kualitatif. Analisis data dalam penelitian ini dilakukan pada saat tindakan, dan setelah tindakan. Data penelitian yang akan diambil terdiri dari hasil observasi, hasil tes setiap tindakan, dan hasil tes semua tindakan. Analisis data yang dipergunakan dalam penelitian mengacu pada mode alir (Miles \& Huberman, 1992), yang meliputi 3 tahap, yaitu (a) reduksi data, (b) penyajian data, (c) penarikan kesimpulan dan verifikasi.

Penjelasan mengenai ketiga tahap tersebut dijelaskan pada bagian berikut ini.

a. Mereduksi data

Mereduksi data adalah proses kegiatan menyeleksi, memfokuskan dan menyederhanakan data yang diperoleh mulai dari awal pengumpulan data sampai penyusunan 
laporan penelitian. Pada dasarnya data yang terkumpul dengan berbagai teknik dan sumber data merupakan data mentah yang masih bersifat kasar. Pada tahap ini data yang terkumpul belum dapat memberikan makna untuk tujuan yang diperlukan. Selain itu kemungkinan besar informasi yang diperoleh masih tumpang tindih dengan adanya teknik pengambilan data yang berbeda. Oleh karena itu, untuk memperoleh informasi yang lebih jelas perlu dilakukan reduksi data. Reduksi data dapat dilakukan antara lain dengan cara memilih, menyederhanakan, menggolongkan dan sekaligus menyeleksi informasi-informasi yang relevan dengan penelitian.

b. Penyajian data.

Penyajian data yang dimaksud adalah penyusunan data secara naratif dari informasi yang telah diperoleh dari proses reduksi dan untuk bahan yang dievaluasi untuk menentukan arah tindakan berikutnya.

c. Penarikan kesimpulan dan verifikasi

Penarikan kesimpulan adalah proses memberikan kesimpulan terhadap hasil penafsiran dan evaluasi. Kegiatan ini mencakup pencarian makna data, dan penjelasan.

\section{Hasil dan Pembahasan}

Sebelum melakukan penelitian, peneliti telah melakukan observasi di lapangan. Observasi berlangsung selama satu semester. Setelah hasilnya diketahui, dibentuk kelompok-kelompok dengan jumlah anggota 5 orang per kelompok. Kelompok disusun atas dasar heterogenitas kemampuan, asal sekolah dan jenis kelamin. Setiap kelompok pada setiap pembelajaran terdiri atas satu ketua kelompok, satu sekretaris, satu presenter, dan satu pembantu umum dengan tugas yang berbeda-beda.

Hasil dan pembahasan penelitian ini semuanya peneliti ringkas dan tampilkan dalam bentuk tabel.

\section{a. Pembahasan dan pembentukan kelompok berdasarkan nilai skor tes awal}

\section{Tabel 5}

Rangkuman pengelompokan kemampuan berdasarkan heterogenitas siswa

\begin{tabular}{lcccc}
\hline Kelompok & $\mathbf{1}$ & $\mathbf{2}$ & $\mathbf{3}$ & $\mathbf{4}$ \\
\hline Jumlah skor & 237.5 & 230 & 232.5 & 242.5 \\
\hline Skor rata-rata kelompok & 47.5 & 46 & 46.5 & 48.5 \\
\hline Skor rata-rata kelas & \multicolumn{5}{c}{47.13} \\
\hline
\end{tabular}

\section{b. Pembahasan berdasarkan nilai skor tes pada tindakan I, II, dan III}

Tabel 6

Rangkuman skor rata-rata kelas dan SPI berdasarkan nilai tes mahasiswa

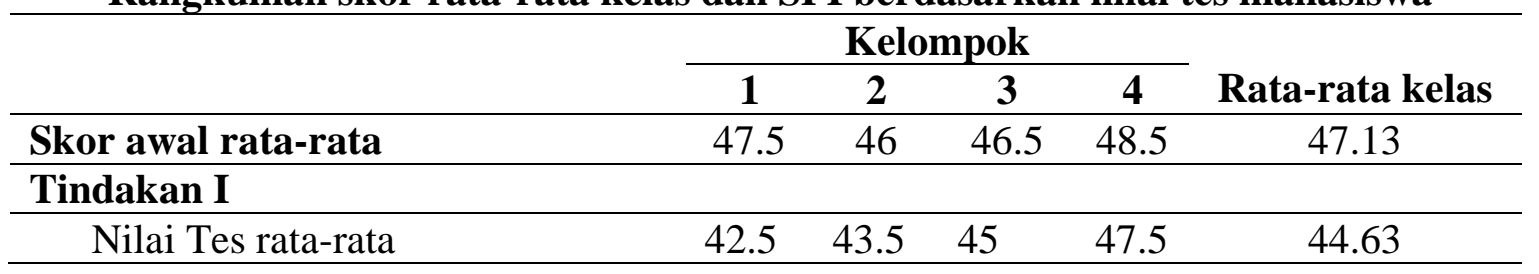




\begin{tabular}{lllllc}
\hline Skor Peningkatan Individu & 10 & 10 & 10 & 10 & 10 \\
\hline Tindakan II & & & & & \\
\hline$\quad$ Nilai Tes rata-rata & 47.5 & 59.5 & 60 & 66.5 & 58.38 \\
\hline$\quad$ Skor Peningkatan Individu & 20 & 30 & 30 & 30 & 19.5 \\
\hline Tindakan III & & & & & \\
\hline$\quad$ Nilai Tes rata-rata & 56 & 65.5 & 68 & 72.5 & $\mathbf{6 5 . 5}$ \\
\hline$\quad$ Skor Peningkatan Individu & 30 & 20 & 20 & 20 & 21 \\
\hline
\end{tabular}

Penjelasan: dimulai dari tindakan pembelajaran pertama sampai ketiga skor meningkat terus, dan skor standart minimum 65 dicapai pada tindakan pembelajaran ketiga.

c. Pembahasan berdasarkan hasil observasi kegiatan dosen di dalam kelas.

Tabel 7

Hasil observasi pengamat terhadap kegiatan dosen di kelas

\begin{tabular}{lccc}
\hline \multirow{2}{*}{ Jenis Kegiatan } & \multicolumn{3}{l}{ Skor Tindakan Kelas ke } \\
\cline { 2 - 4 } Awal & I & II & III \\
\hline - aktivitas sehari-hari & 4 & 4 & 3 \\
\hline - menyampaikan tujuan pembelajaran & 3 & 3 & 4 \\
\hline - membangkitkan pengetahuan awal & 4 & 5 & 5 \\
\hline - menyampaikan manfaat materi & 4 & 3 & 4 \\
\hline - menyajikan materi & 4 & 4 & 4 \\
\hline Inti & & & \\
\hline - membagikan LKM & 4 & 4 & 4 \\
\hline - membentuk kelompok & 4 & 3 & 4 \\
\hline - membimbing kerja kelompok & 3 & 4 & 4 \\
\hline - memandu diskusi kelompok & 4 & 4 & 5 \\
\hline Akhir & & & \\
\hline - melaksanakan tes individu & 4 & 4 & 5 \\
\hline - aktivitas sehari-hari & 3 & 3 & 4 \\
\hline Jumlah skor & 41 & 42 & 46 \\
\hline Ketuntasan: $\frac{\text { jumlahskor }}{\text { skormaksimum }} \times 100 \%=\frac{41}{55} \times 100 \%$ & $74.55 \%$ & $76 \%$ & $\mathbf{8 3 . 6 4 \%}$ \\
\hline
\end{tabular}

Penjelasan: dimulai dari tindakan pembelajaran pertama sampai ketiga skor meningkat terus, dan skor standart minimum $80 \%$ dicapai pada tindakan pembelajaran ketiga. 


\section{d. Pembahasan berdasarkan hasil observasi kegiatan mahasiswa di dalam kelas}

\section{Tabel 8}

\section{Hasil observasi pengamat terhadap kegiatan mahasiswa di kelas}

\begin{tabular}{lccc}
\hline \multirow{2}{*}{ Jenis Kegiatan } & \multicolumn{3}{l}{ Skor Tindakan Kelas ke } \\
\cline { 2 - 4 } Awal & I & II & III \\
\hline - memperhatikan tujuan pembelajaran & & & \\
\hline - membangkitkan pengetahuan awal & 2 & 3 & 4 \\
\hline - keterlibatan memahami manfaat materi & 4 & 4 & 4 \\
\hline - keterlibatan memahami penyampaian materi & 3 & 4 & 4 \\
\hline Inti & 4 & 3 & 5 \\
\hline - keterlibatan mengerjakan LKM & & & \\
\hline - keterlibatan dalam kelompok & 4 & 4 & 4 \\
\hline - keterlibatan menyelesaikan tugas kelompok & 3 & 4 & 5 \\
\hline - aktiviatas mahasiswa berkemampuan tinggi & 4 & 3 & 4 \\
\hline - aktiviatas mahasiswa berkemampuan sedang & 4 & 4 & 5 \\
\hline - aktiviatas mahasiswa berkemampuan rendah & 4 & 3 & 4 \\
\hline - aktivitas mahasiswa dalam diskusi & 3 & 4 & 3 \\
\hline Akhir & 4 & 4 & 4 \\
\hline - kejujuran mengerjakan soal tes & & & \\
\hline Jumlah skor & 3 & 4 & 4 \\
\hline Ketuntasan: $\frac{4}{\text { jumlahskor }} \times 100 \%=\frac{41}{55} \times 100 \%$ & $70 \%$ & $73 \%$ & $\mathbf{8 3 . 3 3 \%}$ \\
\hline
\end{tabular}

Penjelasan: dimulai dari tindakan pembelajaran pertama sampai ketiga skor meningkat terus, dan skor standart minimum $80 \%$ dicapai pada tindakan pembelajaran ketiga.

\section{Kesimpulan}

Berdasarkan hasil penelitian ini, peneliti berpendapat bahwa Pembelajaran Kooperatif Model STAD cukup cocok diterapkan di Perguruan Tinggi Teknik, khususnya di Politeknik Negeri Malang, terkhusus lagi di Program Teknik Listrik karena disamping bisa meningkatkan prestasi akademik, melalui metode ini berbagai ketrampilan sosial bisa diajarkan.

Adapun skenario pembelajaran melalui metode STAD berdasarkan pengalaman selama tindakan pembelajaran antara lain adalah:

\section{a. Penyajian Kelas}

Penyajian kelas menurut pembelajaran kooperatif model STAD, dosen hendaknya memang harus memposisikan diri sebagai fasilitator. Pengetahuan sebaiknya lebih banyak dibangun sendiri oleh mahasiswa secara kooperatif bersama teman-teman kelompoknya.

Penyajian kelas dalam setiap tindakan diawali dengan berbagai tindakan, terutama penjelasan tentang tujuan pembelajaran, manfaaat materi, review singkat materi 
prasyarat, dan materi pokok yang menjadi topik pembicaraan hari itu. Karena esensi pembelajaran ini adalah agar "mahasiswa lebih banyak membangun pengetahuannya sendiri”, maka pembahasan topik utama oleh dosen hanya dibahas secara singkat.

b. Belajar dalam Kelompok

Salah satu tujuan belajar kooperatif adalah memaksimalkan potensi mahasiswa dengan belajar melalui teman-temannya. Untuk mengoptimalkan hasil, mahasiswa dibagi dalam kelompok-kelompok kecil yang terdiri dari 4 sampai 5 orang. Susunan anggota kelompok beragam, artinya secara proporsional setiap kelompok memuat berbagai kriteria yang ada, misalnya, kemampuan akademik, asal sekolah, dan jenis kelamin. Dalam belajar kelompok ini, setiap anggota kelompok dituntut untuk menyumbangkan nilai terbaik bagi kelompoknya, karena dalam pembelajaran ini tingkat keberhasilan diukur atas dasar satuan kelompok.

Disamping adanya pembagian peran dalam setiap kelompok, mahasiswa dalam kelompok yang sama dituntut untuk saling membagi pengetahuannya. Pembagian peran dalam kelompok dapat digunakan sebagai wahana berorganisasi yang kelak berguna bagi mahasiswa setelah terjun di masyarakat dan dunia kerja mereka.

\section{c. Tes Individu}

Pembelajaran kooperatif model STAD merekomendasikan agar tes individu atau tes akhir tindakan dilakukan setelah satu atau dua minggu pertemuan. Disamping menjadi salah satu alat ukur untuk mengetahui tingkat penguasaan terhadap materi pembelajaran, kuis bertujuan memotivasi agar mahasiswa belajar terus. Untuk itu hendaknya soal tes dirancang begitu rupa sehingga menggambarkan mahasiswa aktif membangun pengetahuannya sendiri, belajar terus menerus, belajar secara kolaboratif, memuat pemahaman dan penerapan konsep, serta terkaitkan dengan masalah-masalah teknik sesuai dengan bidang keahlian mahasiswa. Disamping itu, setelah kuis hendaknya lembar jawaban dibagikan kembali kepada mahasiswa untuk memberikan follow up sehingga mahasiswa mengetahui letak kesalahan atau kekurangannya. Banyaknya soal dan waktu yang digunakan tidak perlu terlalu banyak sehingga tidak mengurangi jam untuk topik (materi) lainnya.

\section{d. Skor Peningkatan Individu}

Esensi skor peningkatan individu (SPI) adalah menghargai usaha, sehingga perhitungan skor peningkatan individu lebih ditekankan pada seberapa besar seorang mahasiswa mampu bertahan dan meningkatkan prestasinya. Berdasarkan pengamatan peneliti, skor peningkatan individu ini cukup signifikan, terutama bagi mahasiswa yang memang potensi akademiknya rendah, karena dengan skor tersebut telah memotivasi mahasiswa untuk selalu berusaha meningkatkan prestasinya. Menurut peneliti, skor peningkatan individu ini cukup cocok diberikan di Politeknik, khususnya pada matakuliah Matematika Terapan, mengingat selama ini mahasiswa sulit mencapai nilai akhir tinggi secara mutlak. 


\section{e. Penghargaan Kelompok}

Pada pembelajaran kooperatif model STAD penghargaan diberikan per satuan kelompok berdasarkan predikat yang diperoleh. Predikat ditentukan berdasarkan skor rata-rata kelompok. Caranya adalah menjumlahkan skor sebanyak anggota kelompok, kemudian dibagi banyaknya anggota kelompok. Walaupun penghargaan diberikan kepada kelompok, setiap anggota kelompok harus berusaha menyumbangkan hasil terbaiknya. Karena jika ada anggota kelompok yang nilainya rendah, maka rata-rata nilai kelompok tersebut akan menjadi rendah. Sebaliknya jika semua anggota kelompok nilainya baik, maka nilai rata-rata kelompok menjadi baik. Maka disinilah sesungguhnya esensi belajar kelompok dibentuk, yakni memaksimalkan potensi setiap anggota kelompok dengan cara belajar melalui kelompoknya.

Penghargaan kelompok hendaknya disesuaikan dengan kondisi kelas. Tidak selamanya penghargaan ini berupa materi. Pemberian penghargaan yang selama ini peneliti lakukan hanyalah berupa pujian pada awal pembelajaran atau akhir pembelajaran setelah membagikan kuis dengan menyebut predikat yang berhasil diraih oleh masing-masing kelompok. Ketika diberikan award pada kelompok tertentu biasanya ribut dan terjadi saling meledek antar kelompok.

Mengacu pada hasil penelitian tindakan ini, akhirnya peneliti memberikan kesimpulan antara lain:

a. Pembelajaran matematika terapan di Politeknik hendaknya memang harus melibatkan keaktifan mahasiswa, artinya pembelajaran perlu diupayakan agar mahasiswa lebih banyak membangun pengetahuannya sendiri,

b. Agar pembelajaran suatu topik pembelajaran efektif, hendaknya materi pembelajaran dikaitkan dengan materi sebelumnya, untuk itu materi prasyarat perlu diberikan terlebih dahulu,

c. Agar pembelajaran matematika terapan di Politeknik lebih menarik dan bermanfa'at, hendaknya materi pembelajaran dikaitkan dengan permasalahan-permasalahan yang sesuai dengan bidangnya,

d. Jika metode pembelajaran yang dipilih adalah pembelajaran kooperatif, maka metode pembelajaran metode STAD bisa menjadi pilihan, karena selain bisa meningkatkan pemahaman terhadap materi ajar, mahasiswa juga bisa belajar trampil secara sosial. 


\section{BIBLIOGRAFI}

Hudojo, Herman. (2005). Kapita selekta pembelajaran matematika. Malang: UM Press. Google Scholar

Miles, Matthew B., \& Huberman, A. Michael. (1992). Analisis data kualitatif. Jakarta: UI press. Google Scholar

MUIS, NURFADILLAH. (2020). EFEKTIVITAS PENERAPAN MODEL PEMBELAJARAN KOOPERATIF TIPE STAD BERBANTUAN MEDIA ULAR TANGGA PINTAR TERHADAP HASIL BELAJAR MATEMATIKA KELAS IV SD NEGERI 23 BATARA. UNIVERSITAS COKROAMINOTO PALOPO. Google Scholar

Nurhadi, Burhan Yasin, \& Senduk, Agus Gerrad. (2004). Pembelajaran kontekstual dan penerapannya dalam KBK. Malang: Universitas Negeri Malang Pres. Google Scholar

Slavin, Robert E. (2008). Cooperative Learning: Teori, Riset dan Praktik, Terj. Nurulita, Bandung: Nusa Media. Google Scholar

\section{Copyright holder:}

Mudjiono (2021)

First publication right:

Syntax Literate: Jurnal Ilmiah Indonesia

This article is licensed under:

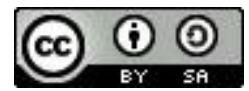

